\title{
Ewolucjonizm przed Darwinem: Matthew, Blyth, Wallace
}

\section{Wstęp}

W listopadzie 1859 roku na półkach angielskich księgarni pojawiła się książka angielskiego przyrodnika Karola Darwina (1809-1882), zatytułowana O powstawaniu gatunków, czyli o utrzymywaniu się doskonalszych ras w walce o byt. Na stronach tej pracy Darwin wyłożył teorię ewolucji drogą doboru naturalnego. Niedługo po jej opublikowaniu pojawiły się krytyczne opinie, że angielski przyrodnik pominął poglądy swoich poprzedników, którzy zajmowali się kwestią naturalnej przemiany, czyli transmutacji gatunków. W trzecim wydaniu swojego opus magnum Darwin zdecydował się na dołączenie rysu historycznego na temat rozwoju poglądu o ewolucji gatunków. Zasadniczym przedmiotem niniejszego tekstu jest analiza dwóch artykułów opublikowanych przed rokiem 1859 - Edwarda Blytha (1835) ${ }^{1}$ i Alfreda Russela Wallace'a (1855), ${ }^{2}$ a także fragmentów książki Patricka Matthew (1831). ${ }^{3}$ Pomimo że po-

\footnotetext{
${ }^{1}$ Por. Edward Blyth, „Próba klasyfikacji «odmian» zwierząt w połączeniu z obserwacjami nietypowych zmian sezonowych i innych, które w sposób naturalny zachodzą u rozmaitych gatunków brytyjskich, lecz nie dają podstaw do wyodrębnienia odmian”, przeł. Grzegorz Malec, Filozoficzne Aspekty Genezy 2015, t. 12, s. 127-146 (oryginał: „An Attempt to Classify the «Varieties» of Animals, with Observations on the Marked Seasonal and Other Changes which Naturally Take Place in Various British Species, and which Do Not Constitute Varieties", The Magazine of Natural History, and Journal of Zoology, Botany, Mineralogy, Geology, and Meteorology 1835, vol. VIII, s. 40-53).

${ }^{2}$ Por. Alfred Russel Wallace, „O prawie, które kierowało pojawianiem się nowych gatunków”, przeł. Grzegorz Malec, Filozoficzne Aspekty Genezy 2015, t. 12, s. 147-166 (oryginał: „On the Law Which Has Regulated the Introduction of New Species", The Annals and Magazine of Natural History, Including Zoology, Botany, and Geology 1855, vol. XVI, s. 184-196).
}

${ }^{3}$ Por. Patrick Matrhew, „O budulcu okrętowym i uprawie drzew oraz krytyczne uwagi o au- 
glądy zawarte na stronach rzeczonych publikacji nie były dotychczas przedmiotem szerszej analizy polskich uczonych, to z pewnością stanowią ważną kartę w historii ewolucjonizmu.

Omawiane teksty zostały poświęcone odrębnym zagadnieniom. Podstawowa różnica między nimi, odzwierciedlona w strukturze niniejszego artykułu, polega na tym, że poglądy Matthew i Blytha, które można uznać za istotne dla historii ewolucjonizmu, są jedynie tłem dla innego, głównego tematu tychże tekstów. Inaczej rzecz ma się z artykułem Wallace'a - tutaj zagadnienie ewolucji jest częścią integralną.

Omawiane teksty mają znaczenie większe niż tylko czysto historyczne. Od dawna bowiem toczą się spory o naukową rzetelność Darwina. Zdaniem niektórych autorów, co warte podkreślenia - ewolucjonistów, autor O powstawaniu gatunków wiele zapożyczył z tekstów Matthew, Blytha i Wallace’a, do czego nigdy się nie przyznał. ${ }^{4}$

torach, którzy ostatnio podejmowali problematykę upraw", przeł. Grzegorz Malec, Filozoficzne Aspekty Genezy 2015, t. 12, s. 109-126 (oryginał: On Naval Timber and Arboriculture; with Critical Notes on Authors Who Have Recently Treated the Subject of Planting, Longman, Rees, Orme, Brown, and Greene - Adam Smith, London - Edinburgh 1831, s. 106-108, 306308, 364-369, 369-375, 381-388).

${ }^{4}$ Por. Roy Davies, The Darwin Conspiracy: Origins of a Scientific Crime, Golden Square Books Ltd., London 2008 (książka Daviesa została omówiona przez Kazimierza Jodkowskiego [por. Kazimierz Jodkowski, „Spisek Darwina”, w: Damian LeszczyŃski (red.), Ewolucja. Filozofia. Religia, Lectiones \& Acroases Philosophicae 2010, vol. III, s. 265-277]); Roy DAVIES, „How Charles Darwin Received Wallace's Ternate Paper 15 Days Earlier Than He Claimed: A Comment on van Wyhe and Rookmaaker (2012)", Biological Journal of the Linnean Society 2012, vol. 105, no. 2, s. 472-477; Loren Eiseley, „Charles Darwin, Edward Blyth, and the Theory of Natural Selection”, Proceedings of the American Philosophical Society 1959, vol. 103, no. 1, s. 94-158; Loren Eiseley, Darwin and the Mysterious Mr. X: New Light on the Evolutionist, J.M. Dent and Sons LTD, London - Toronto - Melbourne 1979, s. 45-93; Mike SutTon, Nullius in Verba: Darwin's Greatest Secret, Thinker Media [First Digital Edition], Kindle Edition 2014. Por. też Jerry Bergman, The Dark Side of Charles Darwin: A Critical Analysis of an Icon of Science, Master Books, Green Forest 2011, s. 139-162; Arnold C. Brackman, A Delicate Arrangement: The Strange Case of Charles Darwin and Alfred Russel Wallace, Times Books, New York 1980. W „Rysie historycznym” zamieszczonym w O powstawaniu gatunków Darwin wymienił Wallace'a i Matthew, ale zdaniem Daviesa i Suttona celowo pomniejszył ich wkład. 


\section{Patrick Matthew (1790-1874)}

\section{A. Nota biograficzna}

Patrick Matthew urodził się 20 października 1790 roku w gospodarstwie zwanym Rome. Był drugim synem Johna Matthew, szkockiego właściciela ziemskiego i sadownika, oraz Agnes Duncan. Wczesną młodość spędził w posiadłości rodziców w Carse of Gowrie (tereny aluwialne w środkowo-wschodniej części Szkocji), którzy prowadzili uprawę drzew owocowych. Pierwsze nauki Matthew pobierał w szkole w Perth. W 1808 roku studiował chemię pod okiem profesora Hope'a. W późniejszym czasie podjął też studia medyczne w Edynburgu, ale po śmierci ojca musiał przerwać naukę (miał wówczas 17 lat) i zająć się prowadzeniem niewielkiego rodzinnego gospodarstwa Gourdiehill. W roku 1817 poślubił swoją kuzynkę Christian Nicoll, z którą miał ośmioro dzieci. Szkocki sadownik interesował się także polityką. W latach trzydziestych wstąpił do ruchu czartystów, z którego wystąpił ostatecznie w 1840 roku na skutek radykalnych poglądów Feargusa O'Connora (1794-1855). Matthew był zdeklarowanym krytykiem dziedziczenia szlachectwa, ustaw zbożowych, funkcjonowania monopoli handlowych, a także nawoływał do poprawy sytuacji klasy robotniczej i opowiadał się za ideami wolnorynkowymi. Uważał, że jedynie kolonizacja nowych obszarów (głównie Nowej Zelandii) może rozwiązać problem bezrobocia w Wielkiej Brytanii. Ponadto był przekonany o cywilizacyjnej misji Brytyjczyków. Matthew często podróżował po Europie. Zapoznał się wówczas $\mathrm{z}$ różnymi metodami upraw drzew. W latach czterdziestych przebywał między innymi w Hamburgu, który był ważnym ośrodkiem handlowym należącym wówczas do Królestwa Pruskiego. Matthew zdecydował się kupić dwie niewielkie farmy, a następnie połączył je w jedno gospodarstwo, którym do 1874 roku zarządzał jego syn Alexander. W latach 1860-1874 często podróżował między swoimi posiadłościami. W tamtym czasie napisał też serię długich listów do Dundee Advertiser, sprzeciwiając się budowie mostu na rzece River Tay, a także podkreślał, że agresorem w wojnie francusko-pruskiej była Francja pod rządami 
Napoleona III (1808-1873). Patrick Matthew zmarł 8 czerwca 1874 roku na skutek choroby serca. ${ }^{5}$

\section{B. Treść tekstu}

W roku 1831 na półkach szkockich i angielskich księgarni pojawiła się książka $O$ budulcu okrętowym i uprawie drzew oraz krytyczne uwagi 0 autorach, którzy ostatnio podejmowali problematykę upraw. Głównym tematem pracy szkockiego sadownika były sposoby uprawy drzew, z których pozyskiwano drewno wykorzystywane do budowy okrętów dla Królewskiej Marynarki Wojennej. Książka zawierała także komentarze dotyczące autorów, którzy wcześniej podejmowali problematykę upraw, jak również poruszała wiele tematów pobocznych: społecznych, politycznych czy ekonomicznych. Przedmiotem mojej analizy są jedynie te fragmenty, które mają znaczenie dla tematu niniejszego tekstu.

Matthew podkreślał, że kondycja drzew owocowych, jak również tych wykorzystywanych w przemyśle, zależy od wielu czynników. Dlatego też hodowca powinien uważnie selekcjonować nasiona i sadzonki, a następnie, w wypadku drzew wykorzystywanych do budowy okrętów, stosować odpowiednie metody uprawy, aby uzyskane drewno było jak najlepszej jakości. Nie powinien jednak, jak twierdził Matthew, naruszać naturalnej równowagi środowiska. ${ }^{6}$

Autor O budulcu okrętowym żywo interesował się kwestiami społecznopolitycznymi. Twierdził, że prawo majoratu — zgodnie z którym cały majątek

\footnotetext{
${ }^{5}$ Szersze informacje biograficzne można znaleźć w: William T. CALman, „Patrick Matthew (1790-1874)”, The Journal of Botany British and Foreign 1912, vol. L, s. 193-194; William T. Calman, „Patrick Matthew of Gourdiehill, Naturalist”, w: A.W. Paton and A.H. Millar (eds.), Handbook and Guide to Dundee and District, British Association for the Advancement of Science, Dundee 1912, s. 451-457; William J. Dempster, Patrick Matthew and Natural Selection: Nineteenth Century Gentleman-Farmer, Naturalist and Writer, Paul Harris Publishing, Edinburgh 1983, s. 9-14; William J. Dempster, Evolutionary Concepts in the Nineteenth Century: Natural Selection and Patrick Matthew, The Pentland Press, Edinburgh - Cambridge Durham 1996, s. 1-8; Walther MAY, „Darwin und Patrick Matthew”, Zoologische Annalen 1911, bd. iv, heft 3, s. 280-295. Por. też John B. BARKer, „Biographical Portrait: Patrick Matthew Forest Geneticist”, Forest History Today Spring/Fall 2001, s. 64-65; Andrew Norman, Charles Darwin: Destroyer of Myths, Skyhorse Publishing, New York 2014, s. 156-157.
}

${ }^{6}$ Por. Matrhew, „O budulcu okrętowym...”, s. 110-113. 
był dziedziczony przez najstarszego potomka linii męskiej — oraz dziedziczenie szlachectwa może doprowadzić i, jak przypuszczał, doprowadzi do rewolucji społecznej, ponieważ majątek szlachecki nie był konsekwencją pracy dziedzica, a wiązał się jedynie z przypadkową okolicznością dobrego urodzenia i odgórnie nadanymi przywilejami. Matthew utrzymywał, że klasa uprzywilejowanej szlachty nie tylko prowadzi do zubożenia niższych warstw społecznych, ale także wstrzymuje rozwój rodzaju ludzkiego. $Z$ drugiej strony twierdził jednak, że szlachta w Wielkiej Brytanii nie uległa zepsuciu tak jak na przykład we Francji. Szkocki sadownik był przekonany, że klasa szlachty, dla własnego dobra, powinna zrezygnować ze wszystkich przywilejów, ponieważ największą satysfakcję daje samodzielnie wypracowany majątek. Rozwój wiedzy i umiejętności sprawił, że istnienie panów feudalnych nie jest już użyteczne dla prawidłowego funkcjonowania państwa. Ludzie, jak twierdził Matthew, mogą sami decydować o własnym losie, a zadowolenie, które mogą czerpać z dobrze płatnej i dobrowolnie podjętej pracy, doprowadzi nie tylko do rozwoju gospodarczego czy poprawy sytuacji klasy robotniczej, ale przede wszystkim do zwiększenia stabilności porządku społecznego. Rola państwa powinna się sprowadzać głównie do zapewnienia bezpieczeństwa obywatelom i ochrony ich własności, a nie do ściągania podatków. ${ }^{7}$ Matthew argumentował na rzecz koncepcji, która w politologii określana jest mianem ,państwa minimalnego”.

Innymi zagadnieniami podejmowanymi przez szkockiego sadownika były zwyczaje i cechy różnych ras ludzkich oraz wpływ zmiany warunków środowiskowych na kondycję danej rasy. ${ }^{8}$

Autor O budulcu okrętowym zauważył również, że człowiek jest najbardziej ekspansywną formą życia. Zajmuje on tereny niemal na każdej szerokości geograficznej, a swoją obecnością zaburza istniejącą w stanie natury równowagę. ${ }^{9}$

\footnotetext{
${ }^{7}$ Por. Matthew, „O budulcu okrętowym...”, s. 113-116.

${ }^{8}$ Por. Matthew, „O budulcu okrętowym...”, s. 116-120.

${ }^{9}$ Por. Matthew, „O budulcu okrętowym...”, s. 124-125.
} 


\section{Poglądy Patricka Matthew a darwinowska teoria ewolucji}

Matthew przez wiele lat zajmował się uprawą drzew owocowych. Wiedział, jakie metody należy stosować, aby wyhodować pożądaną odmianę. W książce O budulcu okrętowym napisał, że człowiek, selekcjonując do rozrodu tylko wybrane osobniki, ukształtował ogromną liczbę odmian zwierząt i roślin:

Zdolność różnicowania w przypadku organizmów najbliższych człowiekowi, które zostały pozbawione naturalnych środowisk i typowych dla siebie zachowań, została przez niego wzniesiona na wyżyny. To pod bacznym okiem człowieka został ukształtowany pies, koń, krowa, owca, ptactwo domowe, jak również jabłoń, grusza, śliwa, agrest, ziemniak czy groch, które występują w niezliczonych odmianach, różniąc się znacznie pod względem rozmiaru owocu, koloru, smaku, stałości budowy i czasu wzrostu — zatem niemalże w każdej dostrzegalnej właściwości. We wszystkich powyższych przypadkach człowiek dokładnie selekcjonuje do rozrodu największze lub najbardziej pożądane jednostki i w ten sposób zapobiega niechcianym zmianom. ${ }^{10}$

Hodowca powinien zwracać równie dużą uwagę na rasę czy określoną odmianę drzew leśnych, jak w przypadku zwierząt domowych — konia, krowy czy owcy. Powinien on wybierać jedynie te nasiona, które pochodzą od większych, zdrowszych i bujnie rosnących drzew, a unikać nasion młodych, jak też starych czy przejrzałych, gdyż może spodziewać się, że wydadzą one, analogicznie do świata zwierząt, ułomne potomstwo, podatne na przedwczesną śmierć. ${ }^{11}$

Na kolejnych stronach książki szkocki sadownik zawarł myśl, że proces selekcji zachodzi również w stanie natury — przedstawiciele poszczególnych gatunków różnią się nieznacznie i zachowują się tylko te jednostki, które są najlepiej przystosowane do warunków środowiskowych:

Wykorzystywanie niezliczonych, wyrastających z nasion odmian w rodzinach roślin, nawet tych dziko rosnących i różniących się ze względu na bujny wzrost i lokalne przystosowanie, wydaje się działać na rzecz wybranych jednostek (najlepiej przystosowanych do warunków środowiskowych), które mogą przerosnąć i stłamsić te słabsze $\mathrm{z}$ tego samego rodzaju, stwarzając tym samym warunki dla pełnego rozrostu i zapewniając ciągły dobór najsilniejszych i najlepiej przystosowanych jednostek. ${ }^{12}$

\footnotetext{
${ }^{10}$ Matthew, „O budulcu okrętowym...”, s. 110-111.

${ }^{11}$ Matthew, „O budulcu okrętowym...”, s. 111.

${ }^{12}$ Matthew, „O budulcu okrętowym...”, s. 112-113.
} 
W kolejnych obszernych fragmentach Matthew wprost wyraził ideę, że w stanie natury rodzi się dużo więcej organizmów niż jest się w stanie zachować. Dlatego dochodzi do rywalizacji, na skutek której giną osobniki gorzej przystosowane, czyli nieposiadające wystarczającej siły, szybkości czy sprytu. $\mathrm{Z}$ tej walki o byt zwycięsko wychodzą tylko organizmy posiadające najwyższy stopień przystosowania i tylko takie są w stanie wydać potomstwo, które z racji swojego pochodzenia będzie miało największe szanse na przedłużenie linii rodowej:

Owo prawo utrzymuje siłę lwa, szybkość zająca i podstępność lisa. Przyrost organizmów w środowisku naturalnym, wraz ze wszystkimi ich modyfikacjami, wykracza daleko poza potrzeby zapełnienia powstałych luk. Osobniki powodowane koniecznością zdobycia pożywienia, które jednak nie posiadają wystarczającej siły, szybkości, odwagi czy sprytu, zginą przedwcześnie i bezpotomnie - padną łupem swoich naturalnych wrogów albo zginą na skutek chorób. Ich miejsce zostanie zajęte przez lepiej przystosowane organizmy pochodzące $z$ tego samego rodzaju, które także poszukują środków do życia. ${ }^{13}$

Samoregulująca skłonność przystosowawcza życia organicznego może po części prowadzić do ogromnej płodności Natury, która, jak zostało stwierdzone, posiada we wszystkich odmianach swojego potomstwa zdolności reprodukcyjne daleko przekraczające (w wielu przypadkach o tysiąckroć) potrzeby wypełnienia powstałych luk. Ponieważ przestrzeń życiowa jest ograniczona i niemal wyczerpana, to jedynie jednostki odważniejsze, odporniejsze i lepiej przystosowane do warunków środowiskowych, zdolne doczekać wieku dojrzałego, zasiedlają miejsca, do których adaptują się lepiej niż jakikolwiek inny ich rodzaj, a jednostki słabsze i gorzej przystosowane są przedwcześnie eliminowane Zasada ta działa nieustannie, regulując ubarwienia, kształty, możliwości i instynkty, a te jednostki każdego gatunku, których wygląd zewnętrzny jest najlepiej przystosowany do maskowania i obrony przed wrogiem czy zmiennością i surowością klimatu; których budowa najlepiej odpowiada potrzebom zapewnienia ochrony, wyżywienia, jak również utrzymania zdrowia i siły; których możliwości i instynkty mogą najlepiej kierować siłą fizyczną w celu uzyskania własnych korzyści względem warunków środowiskowych; tylko te, przy tak ogromnym wytrzebieniu nowonarodzonego i młodego życia, doczekają wieku dojrzałego i wydadzą potomstwo, które sprosta wyzwaniu Natury, sprawdzającej jego zdolności przystosowawcze według kryteriów doskonałości i adaptacji. Z nieustannego działania tego prawa, na mocy którego potomstwo musi przybrać bardziej osobliwe cechy rodziców, razem z obupłciowością roślin i instynktownym ograniczeniem zwierząt do jednostek własnego rodzaju, wynika wyraźna jedność budowy, koloru i usposobienia, co stanowi o gatun-

\footnotetext{
${ }^{13}$ Matthew, „O budulcu okrętowym...”, s. 113.
} 
kach. Rasa stopniowo osiąga najlepsze możliwe przystosowanie do warunków środowiska, w którym żyje, a wraz z ich zmianą sama także ulega przekształceniom, aby dostosować się do zastanych warunków życiowych tak bardzo, jak to tylko możliwe. ${ }^{14}$

Należy pamiętać, że książka szkockiego sadownika ukazała się wiele lat przed opublikowaniem $\mathbf{O}$ powstawaniu gatunków, kiedy jeszcze powszechnie akceptowana była historia stworzenia zapisana na kartach Księgi Rodzaju. Matthew twierdził, że różnorodność życia na Ziemi można wyjaśniać na dwa sposoby: nadnaturalistycznie, czyli odwołując się do cudownych interwencji stwórczych, lub naturalistycznie - poszukując procesów przyrodniczych, które mogły być odpowiedzią na pytanie, jak powstają nowe gatunki. On sam opowiedział się za drugą propozycją:

Na stronicach niniejszego tomu napotykamy poważne trudności — od bezkrytycznie przyjętej klasyfikacji roślin do nieustannego błądzenia między gatunkami a odmianami, które z pewnością przechodzą jedne w drugie na skutek hodowli. Można by mówić o pewnej zgodności, gdyby, zgodnie z maksymą ,każde według jego rodzaju”, nazwane gatunki niewątpliwie istniały w stanie natury. Pogląd ten utrzymywał się przez ostanie 40 wieków. Geologowie znajdują podobną zgodność w skamieniałościach gatunków w głęboko osadzonych warstwach każdej wielkiej epoki. Odkrywają oni jednak ogromne różnice pomiędzy gatunkami lub śladami życia jednej epoki a drugiej. Musimy przeto przyjąć albo wielokrotne cudowne stwarzanie, albo swoistą dla przyrody ożywionej potęgę zmian pod wpływem zmiennych warunków środowiskowych, a raczej natłoku niższych form życia, z których wywodzą się wyższe. Zmienność organizmów żywych wywołana zmianą warunków życiowych na skutek ingerencji człowieka stanowi świadectwo na rzecz poglądu o plastyczności cech wyższych form życia i prawdopodobieństwa, że warunki środowiskowe były bardzo różne w poszczególnych epokach, choć stałe w każdej z osobna, co wskazuje na wysokie prawdopodobieństwo teorii zmian. ${ }^{15}$

W kolejnym akapicie szkocki sadownik pytał retorycznie:

Czy zatem były to niefilozoficzny wniosek, że istoty żywe posiadające zdolności przystosowawcze [...] mogą stopniowo dostosować się do zmiennych warunków środowi-

\footnotetext{
${ }^{14}$ Matthew, „O budulcu okrętowym...”, s. 123.

${ }^{15}$ Matthew, „O budulcu okrętowym...”, s. 120-121.
} 
skowych i bez dodatkowej interwencji stwórczej przedstawiać odmienne przejawy przeszłych i współczesnych form życia? ${ }^{16}$

Matthew był zwolennikiem poglądu Georgesa Cuviera (1769-1832), który twierdził, że w historii Ziemi dochodziło do globalnych katastrof powodujących masowe wymierania gatunków. ${ }^{17}$ Autor $\mathbf{O}$ budulcu okrętowym, w odróżnieniu od Darwina, był przekonany, że transmutacja gatunków zachodzi w stosunkowo niedługim czasie po wielkich katastrofach, a w okresach przejściowych, które, jak twierdził, mogą trwać nawet miliony lat, nie dochodziło do większych zmian w budowie organizmów:

Niszczycielskie pokłady wody, pod wpływem których najtwardsze góry zostały zniszczone i rozdrobnione w żwir, piasek i błoto i które występowały od zarania dziejów, obejmując swoim zasięgiem prawdopodobnie całą powierzchnię globu, wytrzebiając niemalże wszystkie istoty żywe, musiały spustoszyć życie do tego stopnia, że niezamieszkałe obszary mogły zostać zajęte przez nowo powstałe rozgałęzienia form organicznych. Formy te, charakteryzujące się obupłciowością roślin i naturalnymi instynktami zwierząt do życia w stadzie i krzyżowania się z przedstawicielami ich własnego rodzaju, mogły łączyć się w określone grupy. Z biegiem czasu przekształcały się one względem zmian środowiskowych i przystosowywały do niemal każdego rodzaju pożywienia, a po upływie milionów lat stabilności budowy organizmów w poszczególnych epokach, kiedy stopień przystosowania był kompletny, zapewniły pokłady charakterystycznych skamieniałości. ${ }^{18}$

Matthew był zdania, że nowe formy organiczne nie powstają ex nihilo. Jednakże to, że opowiadał się za naturalistyczną koncepcją pochodzenia gatunków, nie znaczy, że jego idea była wolna od czynników celowościowych. Prawo przyrody, o którym pisał, zostało ,_...] zamierzone w celu ukształtowania fizycznych, psychicznych czy instynktownych zdolności dla jak najlepszego jej

\footnotetext{
${ }^{16}$ Matthew, „O budulcu okrętowym...”, s. 121.

${ }^{17}$ Por. Arthur McCalla, The Creationist Debate: The Encounter Between the Bible and the Historical Mind, The Continuum International Publishing Group, London - New York 2006, s. 62-36. Por. też Charles C. Gillispie, Genesis and Geology: The Impact of Scientific Discoveries Upon Religious Beliefs in the Decades Before Darwin, Harper Torchbooks, Harper \& Brothers, New York 1951, s. 98-120.
}

${ }^{18}$ Matthew, „O budulcu okrętowym...”, s. 121-122. 
przystosowania i zapewnienia przetrwania". ${ }^{19} \mathrm{~W}$ kolejnych publikacjach autor O budulcu okrętowym przyznał, że za uniwersalnością praw przyrody stoi jakaś wyższa inteligencja. ${ }^{20}$

Szkocki sadownik traktował teorię doboru naturalnego jak aksjomat. ${ }^{21}$ Kentwood D. Wells zauważył, że była ona dla niego jedynie użyteczną analogią, za pomocą której wyrażał swoje poglądy społeczno-polityczne, twierdząc, że tak jak w przyrodzie nie zachowuje się nic, co nie pełni wartościowych funkcji, tak w stanie społecznym musi dojść do rozpadu klasy szlachty, ponieważ jej obecność wstrzymuje rozwój społeczeństwa. ${ }^{22}$

\section{Edward Blyth (1810-1873)}

\section{A. Nota biograficzna}

Edward Blyth urodził się 23 grudnia 1810 roku. Podobnie jak w przypadku Darwina, bardzo szybko rozwinęły się jego zainteresowania przyrodnicze, które skutecznie udaremniły zamiar zostania duchownym anglikańskim. W roku 1832 otworzył on niewielką aptekę zapewniającą mu skromne dochody, ale na tyle wystarczające, aby mógł rozwijać swoje pasje przyrodnicze. Artykuły młodego ornitologa ukazywały się na łamach The Magazine of Natural History, Field Naturalist oraz The Analyst. W roku 1836 nawiązał współpracę z Towarzystwem Zoologicznym, na którego spotkaniach prawdopodobnie po raz pierwszy spotkał Darwina, Johna Goulda (1804-1881) i Richarda Owena (1804-1892). W odróżnieniu od autora $\mathbf{O}$ powstawaniu gatunków Blyth sam musiał zadbać o swoje utrzymanie. Jego apteka, źle zarządzana, zbankrutowała. Angielski ornitolog bezskutecznie ubiegał się o posadę w Muzeum Brytyjskim. Po tym, jak stanowisko kierownika sekcji ornitologicznej utrzymał George Robert Gray (1808-

\footnotetext{
${ }^{19}$ Matthew, „O budulcu okrętowym...”, s. 113 [wyróżnienie dodane].

${ }^{20}$ Por. Michael E. Weale, „Patrick Matthew's Law of Natural Selection”, Biological Journal of Linnean Society 2015, vol. 115, no. 4, s. 788 [785-791]; Kentwood D. Wells, „The Historical Context of Natural Selection: The Case of Patrick Matthew", Journal of the History of Biology 1973 , vol. 6 , no. 2, s. 251-254 [225-258].

${ }^{21}$ Por. Weale, „Patrick Matthew's Law of Natural Selection...”, s. 789.

${ }^{22}$ Por. Wells, „The Historical Context of Natural Selection...”, s. 231-242.
} 
1872), postanowił wyjechać do Kalkuty, aby tam podjąć pracę kustosza w Muzeum Towarzystwa Azjatyckiego Bengalu. Ornitolog przebywał w Azji w latach 1841-1862. W tym czasie liczba eksponatów muzealnych zwiększyła się do tego stopnia, że większość z nich z powodu braku miejsca trafiała do magazynu i była niedostępna dla odwiedzających. Blyth usprawnił również sposób funkcjonowania tej placówki. Za jego kadencji nastąpił ogromny wzrost liczby odwiedzających. Przybycie angielskiego przyrodnika do Kalkuty uznano za jeden z przełomowych momentów dla indyjskiej zoologii, a jego samego określono mianem „Ojca Indyjskiej Ornitologii”. ${ }^{23}$ W roku 1854 ożenił się z Elizabeth Mary Turner Hodges (1825-1857), która zmarła na zapalenie wątroby w grudniu 1857 roku. Blyth przez cały okres pobytu w Azji usiłował zwiększyć swoje dochody, dlatego od 1844 roku prowadził handel zwierzętami - swoje usługi, co warto podkreślić, proponował między innymi Darwinowi. W roku 1862 ze względu na pogarszający się stan zdrowia zdecydował się wrócić do Anglii i zamieszkał w Londynie. Jeszcze w okresie kalkuckim nawiązał kontakt korespondencyjny z Darwinem, dostarczając mu rozmaitych informacji przyrodniczych, które ten wykorzystywał w swoich książkach. Przyrodnicy spotkali się w domu Darwina w roku 1868. Po powrocie do Anglii Blyth nadal rozwijał swoje zainteresowania zoologią (szczególnie ornitologią), dopóki jego stan zdrowia znacznie się nie pogorszył w drugiej połowie 1873 roku. Zmarł na zawał serca 27 grudnia 1873 roku. ${ }^{24}$

${ }^{23}$ James A. Murray, The Avifauna of British India and Its Dependencies: A Systematic Account, with Descriptions of All the Known Species of Birds Inhabiting British India, Observations On Their Habits, Nidification, \&c., Tables of Their Geographical Distribution in Persia, Beloochistan, Afghanistan, Sind, Punjab, N.W. Provinces, and the Peninsula Of India Generally, with Woodcuts, Lithographs, and Coloured Illustrations, vol. 1, Trübner \& Co., Education Society Press, London - Bombay 1888, s. xiv.

${ }^{24}$ Szersze informacje biograficzne można znaleźć w: Arthur Grote, „Introduction (Memoir of Edward Blyth)", w: Edward Bцyтн, Catalogue of Mammals and Birds of Burma, with a Memoir, and Portrait of the Author, Journal of the Asiatic Society of Bengal part II (Extra Number, August 1875), Stephen Austin and Sons, Hertford 1875, s. iii-xxiv; Christine Brandon-Jones, „A Clever, Odd, Wild Fellow: The Life and Work of Edward Blyth, Zoologist, 1810-1873”, Hamadryad 2006, vol. 31, no. 1, s. 1-175; Grzegorz MALEC, „Edward Blyth (1810-1873). Ojciec Indyjskiej Ornitologii”, Kwartalnik Historii Nauki i Techniki 2014, R. 59, nr 1, s. 109-133). Por. też Christine Brandon-Jones, „Charles Darwin and the Repugnant Curators”, Annals of Sciences 1996, no. 53, s. 501-510; Christine Brandon-Jones, „Edward Blyth, Charles Darwin, and the Animal Trade in Nineteenth-Century India and Britain”, Journal of the History of Biology 1997, vol. 


\section{B. Treść tekstu}

W roku 1835 na łamach The Magazine of Natural History ukazał się tekst „Próba klasyfikacji «odmian» zwierząt w połączeniu z obserwacjami nietypowych zmian sezonowych i innych, które w sposób naturalny zachodzą u rozmaitych gatunków brytyjskich, lecz nie dają podstaw do wyodrębnienia osobnych odmian". Jego autorem był mało wówczas znany przyrodnik Edward Blyth, który na stronach swojego tekstu zwrócił uwagę, że termin „odmiana” był powszechnie stosowany w odniesieniu do zbyt wielu przypadków zmian w świecie zwierząt, dlatego postanowił on podjąć próbę sporządzenia ich klasyfikacji. Pomimo trudności z występowaniem stanów pośrednich między różnymi odmianami, Blyth zaproponował ich podział na cztery grupy: odmiany proste, odmiany nabyte, rasy i odmiany prawdziwe. ${ }^{25}$

Odmiany proste (drobne odmiany osobnicze) dotyczą jedynie niewielkich odchyleń budowy fizycznej poszczególnych gatunków. W stanie natury często zanikają one na przestrzeni kilku pokoleń. Najbardziej charakterystycznym przykładem tego typu odmiany były w opinii Blytha albinosy. ${ }^{26}$

Odmiany nabyte powstają na skutek różnych czynników środowiskowych, jak na przykład wpływ różnego rodzaju pożywienia czy zmiany warunków klimatycznych danego obszaru, i charakteryzują się między innymi różnicami ubarwienia oraz wielkości zwierząt. Odmiany tego typu, jak podkreślał angielski ornitolog, mają tendencję do zanikania w przypadku usunięcia czynnika je powodującego. ${ }^{27}$

Trzecią klasą odmian były według Blytha rasy. Najczęściej powstawały one w wyniku działalności człowieka, który dopuszczał tylko jednostki posiadające odpowiednie cechy. Przykładami odmian, które powstały w ten sposób, były różne rasy bydła czy gołębi. Przy braku ingerencji człowieka, podobnie jak

30, no. 2, s. 145-178; Christine Brandon-Jones, „Long Gone and Forgotten: Reassessing the Life and Career of Edward Blyth, Zoologist”, Archives of Natural History 1995, vol. 22, no. 1, s. 9195 .

\footnotetext{
${ }^{25}$ Por. BLYth, „Próba klasyfikacji «odmian»...”, s. 128.

${ }^{26}$ Por. Вцүтн, „Próba klasyfikacji «odmian»...”, s. 128-131.

${ }^{27}$ Por. Bцyтн, „Próba klasyfikacji «odmian»...”, s. 131-134.
} 
w przypadku odmian nabytych, rasy również wykazywały tendencję do powrotu do typu pierwotnego. ${ }^{28}$

Odmiany prawdziwe odnosiły się do takich przypadków, w których poszczególne osobniki zachowują się jedynie na skutek działalności człowieka, a w stanie natury miałyby niewielkie szanse na utrzymanie i wydanie potomstwa. Na przykład różne rasy owiec, ale także ,jednokopytna (oślostopa) odmiana świni, bezogonowe koty, pozbawione upierzenia, pięciopalczaste i bezogonowe ptactwo domowe, a także wiele rodzajów psów i prawdopodobnie rasa gołębi pawików". ${ }^{29}$ Odmiany tego typu zostały określone przez Blytha mianem prawdziwych, ponieważ nie powracają one do typu pierwotnego. Warto podkreślić, że do tej klasy odmian angielski ornitolog zaliczył różnych przedstawicieli gatunku ludzkiego. Odmiany prawdziwe mają charakter wrodzony, ale ich pierwsze pojawienie się mogło być konsekwencją warunków środowiskowych. ${ }^{30}$

W dalszej części tekstu Blyth opisywał zmiany zachodzące w budowie fizycznej zwierząt, które mają głównie charakter okresowy (zależny od pory roku) i które nie mają wpływu na powstanie odmian. Angielski ornitolog skupił się głównie na zmianach w ubarwieniu. ${ }^{31}$

\section{Poglądy Edwarda Blytha a darwinowska teoria ewolucji}

Blyth podkreślał, że w stanie przyrody zachodzi walka o byt. Jednostki najlepiej przystosowane mają największe szanse na zdobycie pożywienia, doczekanie wieku reprodukcyjnego i spłodzenie potomstwa, które w sposób naturalny przejmie te sprzyjające cechy od swoich rodziców:

W dużym stadzie bydła najsilniejszy byk przegania ze stada mniejsze i słabsze osobniki tej samej płci i pozostaje jedynym jego panem. Dlatego też wszystkie rodzące się młode pochodzą od osobnika mającego największe możliwości i siłę fizyczną, który, w związku z tym, w walce o byt najlepiej potrafił utrzymać swoją pozycję i obronić się przed każdym wrogiem. W podobny sposób pośród zwierząt, które zawdzięczają zdo-

\footnotetext{
${ }^{28}$ Por. BLyth, „Próba klasyfikacji «odmian»...”, s. 134-136.

${ }^{29}$ B Lyтн, „Próba klasyfikacji «odmian»...”, s. 136.

${ }^{30}$ Por. Bцyтн, „Próba klasyfikacji «odmian»...”, s. 136-138.

${ }^{31}$ Por. Bцyтн, „Próba klasyfikacji «odmian»...”, s. 140-143.
} 
byte pożywienie swojej sprawności, sile lub wrażliwości zmysłów, jednostka najlepiej uposażona musi zawsze uzyskać największe zasoby i siłę fizyczną. I tym sposobem, na skutek zdobycia przewagi nad konkurentami, uzyskuje możliwość przekazania tychże jakościowo najlepszych cech większej liczbie potomstwa. ${ }^{32}$

W tym samym akapicie Blyth napisał również:

[...] każda rasa rozpowszechnia się głównie za sprawą najbardziej reprezentatywnych i najdoskonalszych osobników. ${ }^{33}$

Angielski ornitolog był przekonany, że w przyrodzie występuje powszechne prawo, na mocy którego potomstwo zawsze przypomina rodziców. Twierdził również, że człowiek, selekcjonując do rozrodu tylko osobniki posiadające pożądane cechy, może otrzymać nowe odmiany, a nawet rasy poszczególnych gatunków, które będą znacznie odbiegały od typu pierwotnego:

Zgodnie z powszechnym prawem przyrody wszystkie stworzenia wydają zbliżone sobie potomstwo i prawo to rozciąga się nawet na najpospolitsze drobiazgi, najmniejsze osobnicze cechy szczególne. Dlatego w przypadku ludzi dostrzegamy rodzinne podobieństwo przenoszone z pokolenia na pokolenie. Kiedy dobierze się para zwierząt, a każde z nich ma jakieś niepowtarzalne cechy, nieważne jak błahe, to najczęściej cechy te w sposób naturalny ulegają wzmocnieniu. Jeżeli potomstwo tych zwierząt zostanie rozdzielone i tylko te, w których te same cechy są najwidoczniejsze, zostaną wyselekcjonowane do rozrodu, to następna generacja będzie posiadać te cechy w jeszcze większym stopniu i tak dalej do czasu, kiedy utworzy się odmiana, którą określam mianem rasy i która może być bardzo niepodobna do pierwotnego typu. ${ }^{34}$

Blyth zdawał sobie sprawę również $\mathrm{z}$ tego, że w pewnych przypadkach (przyrodnik miał na myśli głównie ludzi) sukces reprodukcyjny nie wynika $\mathrm{z}$ tężyzny fizycznej czy sprytu, ale jest skutkiem, jak twierdził, wrodzonej skłonności do najatrakcyjniejszych jednostek:

Być może jednak nie będzie to impertynencją, jeśli zaznaczę tutaj, że tak jak w stanie natury, dzięki mądrym zasadom zabezpieczającym, typowe cechy gatunków ulegają zachowaniu ze względu na to, że rozmnażają się głównie jednostki, których budowa

\footnotetext{
${ }^{32}$ Bцүтн, „Próba klasyfikacji «odmian»...”, s. 135.

${ }^{33}$ B

${ }^{34}$ B цутн, „Próba klasyfikacji «odmian»...”, s. 134-135.
} 
jest najdoskonalsza i które z racji dysponowania większą energią i fizycznymi możliwościami są w stanie pokonać i przepędzić osobniki słabe i chore, tak i w przypadku rasy ludzkiej degeneracji w dużej mierze zapobiega wrodzona i naturalna preferencja dla najatrakcyjniejszych jednostek. ${ }^{35}$

Niemniej w opinii angielskiego ornitologa to, co Darwin określał mianem doboru płciowego, nie ma większego znaczenia w stanie natury:

Wszystko wskazuje na to, że w przypadku zwierząt niższych atrakcyjny wygląd zewnętrzny nie ma najmniejszego znaczenia. Najróżniejsze odmiany tego samego gatunku krzyżują się między sobą tak swobodnie i łatwo jak najbardziej reprezentatywne osobniki, przy czym faworyzowany jest po prostu najsilniejszy. ${ }^{36}$

Należy podkreślić, że na początku dziewiętnastego wieku dominowała idea o niezmienności gatunków, łączona już od czasów średniowiecznych z tradycją chrześcijańską. Uznawano wówczas, że Wszechświat jest statyczny. ${ }^{37}$ Jak napisał Stanisław Skowron (1900-1976), polski biolog i popularyzator ewolucjonizmu:

Każdy gatunek został stworzony, aby stanowić określone ogniwo w gospodarce przyrody. Każdemu gatunkowi został jak gdyby wyznaczony odpowiedni teren, każdy gatunek został z natury wyposażony w większą lub mniejszą zdolność do zmienności zależnie od tego, czy zasiedlił tereny o rozmaitym zespole warunków, czy też okolice odznaczające się monotonią. Lecz nawet i w pierwszym przypadku nigdy zmienność gatunku nie mogła przekroczyć ustalonych z góry granic. ${ }^{38}$

Blyth swoimi poglądami wpisywał się w ten nurt. Mimo że wiele lat przed Darwinem przedstawił koncepcję doboru naturalnego, która dla autora $\mathbf{O}$ powstawaniu gatunków była odpowiedzią na zagadnienie powstawania nowych gatunków, to postrzegał ją jako mechanizm konserwujący (stabilizujący) ${ }^{39}$ dzia-

\footnotetext{
${ }^{35}$ BцYтн, „Próba klasyfikacji «odmian»...”, s. 139.

${ }^{36}$ Вцутн, „Próba klasyfikacji «odmian»...”, s. 139.

${ }^{37}$ Por. Kazimierz Jоркошsкі, Metodologiczne aspekty kontrowersji ewolucjonizm-kreacjonizm, Realizm. Racjonalność. Relatywizm, t. 35, Wyd. UMCS, Lublin 1998, s. 208.

${ }^{38}$ Stanisław SKowron, Narodziny wielkiej teorii. Karol Darwin i jego poprzednicy, Wiedza Powszechna, Warszawa 1965, s. 87.

${ }^{39}$ Jak podkreślił Adam Urbanek, w literaturze częściej używa się określenia „dobór normali-
} 
łający na rzecz niezmienności gatunków. Mieczysław Pajewski, założyciel Polskiego Towarzystwa Kreacjonistycznego, napisał: „Blyth uważał dobór naturalny za proces przystosowujący odmiany stworzonych typów do różnych środowisk". ${ }^{40}$ Wydaje się jednak, że angielski ornitolog postrzegał granicę dla zmienności organicznej na poziomie gatunków. Jak oznajmił Skowron, ,[...] Blyth dobrze zdawał sobie sprawę z jednego tylko aspektu działania doboru, aspektu stabilizującego. Dobór jest mechanizmem utrzymującym w ryzach zmienność, zapewniającym niezmienność gatunków". ${ }^{41}$ Blyth był przekonany, że jeżeli w przyrodzie pojawiają się odmiany znacząco odbiegające od pierwotnego typu gatunkowego, to zostaną wyeliminowane. Tym sposobem najbardziej reprezentatywni przedstawiciele poszczególnych gatunków uzyskają najwięcej szans re-

zujący” (por. Adam UrbaneK, „Przedmowa do wydania polskiego”, w: Iwan I. Szmalhauzen, Czynniki ewolucji. Teoria doboru stabilizującego, przeł. Irena Zubkiewicz, PWN, Warszawa 1975). Koncepcja stabilizującego doboru naturalnego została szeroko przeanalizowana w I połowie dwudziestego wieku (por. Iwan I. Schmalhausen, Organizm jako całość w rozwoju indywidualnym i historycznym, przeł. Stanisław Dąbrowski, Książka i Wiedza, Warszawa 1962). W literaturze jest on przedstawiany w sposób następujący: „W przypadku, gdy populacja znajduje się we względnie stałych warunkach środowiska, dobór działa w sposób zachowawczy, tj. przeciwstawia się wszelkim odchyleniom od normy i wpływom naruszającym przekaz informacji genetycznej lub jej przekształcenia [...]" (Benedykt HaLICZ, Procesy ewolucji biologicznej, Państwowe Wydawnictwo Naukowe, Warszawa 1972, s. 130-131); „W środowisku stałym dobór naturalny jest na ogół siłą konserwatywną, która sprzyja stabilności i działa na niekorzyść mutantów. Ta ważna, chociaż mało efektywna forma selekcji, nosi nazwę doboru normalizującego [...]. Normalizujący dobór naturalny stale i niezmordowanie usuwa z populacji geny szkodliwe" (Theodosius Dobzhansky, Dziedziczność a natura czlowieka, przeł. Marian Jurecki, Współczesna Biblioteka Naukowa Omega, t. 113, Państwowe Wydawnictwo Naukowe, Warszawa 1968, s. 135).

${ }^{40}$ Mieczysław PaJewski, Stworzenie czy ewolucja?, Wydawnictwo „Duch Czasów”, BielskoBiała 1992, s. 59. Por. też PAJEwski, Stworzenie czy ewolucja..., s. 66.

${ }^{41}$ SKowron, Narodziny wielkiej teorii..., s. 84. Por. też Peter J. Bowler, Darwin Deleted: Imagining a World without Darwin, The University of Chicago Press, Chicago - London 2013, s. 56; William Coleman, „Lyell and the «Reality» of Species: 1830-1833”, Isis 1962, vol. 53, no. 3, s. 338 [325-338]; Gavin DE BeER, ,Some Unpublished Letters of Charles Darwin”, Notes and Records of the Royal Society of London 1959, vol. 14, no. 1, s. 13 [12-66]; Gavin DE BeER, Charles Darwin: A Scientific Biography, The Natural History Library, Anchor Books — Doubleday \& Company, Inc., New York 1964, s. 103; Thomas B. Fowler and Daniel Kuebler, The Evolution Controversy: A Survey of Competing Theories, Baker Academic, Grand Rapids 2007, s. 27; Gertrude Himmelfarb, ,The Evolution of an Idea”, The New York Times 6 July 1980, s. 7 [710]; Joel S. SchwarTz, „Charles Darwin's Debt to Malthus and Edward Blyth”, Journal of the History of Biology 1974, vol. 7, no. 2, s. 303 [301-318]. 
produkcyjnych, toteż stabilność wewnątrzgatunkowa zostanie podtrzymana. W artykule z 1835 napisał:

Gatunki, w swej pierwotnej formie, są niewatpliwie lepiej przystosowane do swojego naturalnego środowiska niż jakiekolwiek ich modyfikacje. Gdy popęd płciowy pobudza do rywalizacji i konfliktu, przy czym silniejszy musi zawsze dominować nad słabszym, to w stanie natury gatunki zmodyfikowane mają niewiele możliwości, by kontynuować swoją rasę ${ }^{42}$

Znaczna część tekstu Blytha została poświęcona kwestii ubarwienia gatunków, które jego zdaniem zostało zamierzone przez Opatrzność, a zatem nie było skutkiem działania procesu czysto przyrodniczego, jak to zostało sformułowane w teorii Darwina. Angielski ornitolog oznajmił:

[...] istnieją różnice w opiniach przyrodników co do tego, czy te sezonowe zmiany ubarwienia były zamierzone przez Opatrzność jako adaptacja do zmian temperatury, czy jako ochrona różnorodnych gatunków, poprzez dostosowanie ich ubarwienia do kolorów otoczenia, przed możliwością dostrzeżenia ich przez wrogów. Wbrew temu drugiemu przekonaniu wystarczająco wiarygodnie dowiedziono, że „natura działa na rzecz tak napastnika, jak ofiary”. Faktem jest, że zmiany sezonowe służą obu celom i znajdują się one pośród wyrazistych przykładów projektu, który tak jasno i przekonująco poświadcza istnienie wielkiej, wszechwiedzącej Pierwszej Przyczyny. Wyniki eksperymentów przemawiają za trafnością pierwszej opinii, a można też wskazać wystarczające dowody, że i druga jest trafna. ${ }^{43}$

W obu przypadkach ubarwienie jest niewątpliwie zamierzone dla tego samego celu, jakim jest ukrycie się. ${ }^{44}$

Myślę, że na podstawie obserwacji tak wielu bardzo uderzających przystosowań ubarwienia do miejsca przebywania, w przypadkach, w których zapewniony tym sposobem kamuflaż może być jedynym celem, nie jest trudno wywnioskować, że zmiany ubarwienia u wielu arktycznych zwierząt były zamierzone przez Opatrzność dla dwojakiego celu, mianowicie dla utrzymania ciepłoty ciała, jak również umożliwienia im ukrycia się przed wzrokiem przeciwnika. ${ }^{45}$

\footnotetext{
${ }^{42}$ B

${ }^{43}$ B Lyтн, „Próba klasyfikacji «odmian»...”, s. 141.

${ }^{44}$ Bцутн, „Próba klasyfikacji «odmian»...”, s. 143.

${ }^{45}$ B цутн, „Próba klasyfikacji «odmian»...”, s. 143.
} 
To samo prawo, które zostało zamierzone przez Opatrzność do podtrzymywania typowych cech danego gatunku, może być łatwo wykorzystane przez człowieka do wyhodowania różnorodnych odmian. ${ }^{46}$

Do roku 1859, czyli do opublikowania O powstawaniu gatunków, bardzo popularny był pogląd, że świat natury jest doskonale harmonijnym tworem, w którym prawa przyrody są odzwierciedleniem boskiego zamysłu. ${ }^{47}$ Poglądy ornitologa doskonale korespondują z taką wizją przyrody. ${ }^{48}$ Skowron, charakteryzując stanowisko Blytha, napisał:

Cały świat istot żywych przedstawia [...] obraz pełnej harmonii i porządku, który nie rodził się stopniowo, nie był wyrazem dynamiki rozwojowej, lecz w gotowej postaci został stworzony $\mathrm{i}$ wyposażony w rządzące nim prawa, nie dozwalające na zaburzenie jego harmonijnego układu. ${ }^{49}$

Warto i w tym wypadku przytoczyć słowa angielskiego przyrodnika:

Jak pięknie tym sposobem spostrzegamy, podobnie jak w tysiącu innych przypadków, równowagę zachowywaną w stanie natury. I nawet tutaj widzimy inny powód, dla którego chorowite lub zwyrodniałe zwierzęta (mam na myśli te, które są w stanie jedynie w mniejszym stopniu utrzymać niezbędną czujność) muszą niebawem zniknąć, a najdrobniejsze odchylenie od naturalnego ubarwienia musi zazwyczaj okazać się zgubne dla swojego nosiciela. ${ }^{50}$

Edward Blyth był kreacjonistą. Jego teoria w gruncie rzeczy była diametralnie inna niż ta zaproponowana przez Darwina na stronach O powstawaniu ga-

${ }^{46}$ Bцутн, „Próba klasyfikacji «odmian»...”, s. 135.

${ }^{47}$ Pogląd taki przedstawiał między innymi William Paley (por. Robert Brennan, Describing the Hand of God: Divine Agency and Augustinian Obstacles to the Dialogue between Theology and Science, Pickwick Publications, Eugene 2015, s. xv. Por. też Jan Marten Ivo KLAver, Geology and Religious Sentiment: The Effect of Geological Discoveries on English Society and Literature between 1829 and 1859, Brill's Studies In Intellectual History, Brill, Leiden - New York Köln 1997, s. 59; Kostas Kampourakis, Understanding Evolution, Cambridge University Press, Cambridge - New York 2014, s. 108).

${ }^{48}$ Por. Jan SAPP, Genesis: The Evolution of Biology, Oxford University Press, New York 2003, s. 23.

${ }^{49}$ Skowron, Narodziny wielkiej teorii..., s. 87.

${ }^{50}$ Bцутн, ,Próba klasyfikacji «odmian»...”, s. 144. 
tunków. Niemniej zdawał on sobie sprawę, że w przyrodzie zachodzi walka o byt - że tylko jednostki najlepiej przystosowane do warunków środowiskowych mogą doczekać wieku dojrzałego i wydać potomstwo, które z racji swojego pochodzenia będzie miało szansę na kontynuowanie linii rodowej - i głównie $\mathrm{z}$ tego względu jego poglądy można uznać za znaczące dla historii ewolucjonizmu.

\section{Alfred Russel Wallace (1823-1913)}

\section{A. Nota biograficzna}

Alfred Russel Wallace urodził się 8 stycznia 1823 roku w walijskiej wiosce Llanbadoc. Był ósmym dzieckiem Thomasa Vere'a Wallace'a (1771-1843) i Mary Ann Wallace (1792-1868). W wieku czternastu lat musiał opuścić szkołę i zacząć pracować na własne utrzymanie. Przyszły przyrodnik zamieszkał w Londynie i po krótkim czasie spędzonym u swojego brata Johna (1818-1895) podjął pracę $\mathrm{w}$ charakterze pomocnika mierniczego, którym był również jeden $\mathrm{z}$ jego braci - William (1809-1845). Praca ta wymagała częstych podróży, podczas których Wallace zainteresował się historią naturalną. Na początku 1844 roku musiał on jednak zmienić zajęcie i poszukać innego źródła dochodów. W tym samym roku przeczytał słynny esej Thomasa Malthusa (1766-1834), Prawo ludności, ${ }^{51}$ a w roku 1845 zapoznał się z anonimowo opublikowaną pracą Vestiges of the Natural History of Creation (jej autorem, jak się później okazało, był Robert Chambers (1802-1871)), ${ }^{52}$ po lekturze której został ewolucjonistą. W towarzystwie swojego przyjaciela Henry'ego Waltera Batesa (1825-1892) wyruszył w roku 1848 na czteroletnią wyprawę w rejony tropikalne Ameryki Południowej. Koszty podróży zostały pokryte przez Samuela Stevensa (1817-

\footnotetext{
${ }^{51}$ Por. Thomas R. Malthus, Prawo ludności, przeł. K. Stein, Biblioteka Myśli Społecznej, Jirafa Roja, Warszawa 2007.

${ }^{52}$ Autor anonimowy [Robert Chambers], Vestiges of the Natural History of Creation, John Churchill, London - Edinburgh 1844. Obszerne studium poglądów Chambersa przedstawił w setną rocznicę opublikowania O powstawaniu gatunków Milton Millhauser (por. Milton Millhauser, Just Before Darwin: Robert Chambers and Vestiges, Wesleyan University Press, Middletown 1959). Por. też James A. SECORD, Victorian Sensation: The Extraordinary Publication, Reception, and Secret Authorship of Vestiges of the Natural History of Creation, University of Chicago Press, Chicago 2000.
} 
1899), a ten w zamian miał otrzymać znaczną część zgromadzonych okazów przyrodniczych. Był to okres bardzo produktywny w życiu Wallace'a. Nie tylko zebrał wówczas ogromną kolekcję owadów, ale także rozmyślał nad kwestią adaptacji gatunków do różnych warunków środowiskowych. W roku 1852 wyruszył w podróż powrotną do Anglii, podczas której na żaglowcu „Helen” wybuchł pożar. Ogien strawił wszystkie zdobycze Wallace'a, a on sam ledwie uszedł z życiem. Po dwóch latach zdecydował się na kolejną wyprawę, tym razem w regiony Archipelagu Malajskiego. Walijski przyrodnik spędził w Azji następne osiem lat. W tym czasie napisał swój najbardziej znany tekst, „O dążności odmian do nieograniczonego odbiegania od typu pierwotnego", ${ }^{53}$ dzięki któremu został uznany za niezależnego twórcę teorii ewolucji drogą doboru naturalnego. Idea ta pojawiła się w umyśle Wallace'a, kiedy cierpiał na wysoką gorączkę będącą skutkiem malarii. Przypomniał sobie wówczas poglądy Malthusa i zrozumiał, jak zmieniają się gatunki. W roku 1862 Wallace wrócił do Anglii i był już uważany za jednego z czołowych przyrodników. Sława, którą się cieszył, nie przełożyła się jednak na wzrost dochodów. W tamtym czasie zainteresował się także spirytyzmem, co wzbudzało mieszane uczucia wśród naukowego establishmentu dziewiętnastowiecznej Anglii. ${ }^{54} \mathrm{~W}$ roku 1866 poślubił Annie Mitten (1846-1914), z którą miał troje dzieci. W latach siedemdziesiątych Wallace utrzymywał się głównie ze swoich publikacji wydawanych dzięki finansowej pomocy między innymi Charlesa Lyella (1797-1875) i Darwina. W roku 1881, również przy znacznym udziale Darwina, otrzymał niewielkie świadczenie emerytalne, co pozwoliło mu na utrzymanie rodziny. ${ }^{55}$ Pod koniec 1886 roku walijski podróżnik wybrał się w dziesięciomiesięczną podróż do Stanów Zjednoczonych, podczas której prowadził odczyty na temat teorii ewolucji. W roku 1889, już po śmierci autora O powstawaniu gatunków, ukazało się wyczerpujące studium ewolucjonistycznych poglądów Wallace'a i Darwina.

\footnotetext{
${ }^{53}$ Por. Alfred R. WALlace, „O dążności odmian do nieograniczonego odbiegania od typu pierwotnego", przeł. Kazimierz Szarski, w: Kazimierz Petrusewicz (red.), Teoria ewolucji w wypisach, Wiedza Powszechna, Warszawa 1959, s. 81-91.

${ }^{54}$ Książka Wallace'a, On Miracles and Modern Spiritualism, została przetłumaczona na język polski (por. Alfred Russel Wallace, $O$ cudach i nowoczesnym spirytyzmie, przeł. J.K. Potocki, Oficyna Wydawnicza RIVAIL, Warszawa 2011).

${ }^{55}$ Por. Ralph CoLp, Jr., „«I Will Gladly Do My Best»: How Charles Darwin Obtained a Civil List Pension for Alfred Russel Wallace”, Isis 1992, vol. 83, no. 1, s. 2-26.
} 
Walijski przyrodnik, oddając hołd Darwinowi, nadał mu tytuł Darwinism. ${ }^{56}$ Wallace zmarł 7 listopada 1913 roku i został pochowany na cmentarzu w Broadstone. ${ }^{57}$

\section{B. Poglądy Alfreda Russela Wallace'a a darwinowska teoria ewolucji}

Cztery lata przed opublikowaniem $\mathbf{O}$ powstawaniu gatunków ukazał się artykuł „O prawie, które kierowało pojawianiem się nowych gatunków”. W tekście tym Wallace skupił swoją uwagę na zagadnieniu rozmieszczenia geograficznego zwierząt i roślin. Walijski podróżnik wypowiadał się w duchu uniformitaryzmu Lyella, ${ }^{58}$ twierdząc, że badania geologiczne wskazują na powolne przeobrażenia powierzchni Ziemi, które odbywały się w ogromnych odstępach czasu. ${ }^{59}$ Wallace był zdania, że „,[...] obecny stan Ziemi i organizmów ją za-

\footnotetext{
${ }^{56}$ Por. Alfred Russel Wallace, Darwinism: An Exposition of the Theory of Natural Selection with Some of Its Applications, Macmillan and Co., London - New York 1889. Marcin Ryszkiewicz, geolog i znany popularyzator nauki, przełożył i komentarzami opatrzył obszerne fragmenty tej pracy (por. Marcin Ryszkiewicz, Alfred Russel Wallace. W cieniu Darwina, przeł. Marcin Ryszkiewicz, Biblioteka Klasyków Nauki, Wydawnictwa Uniwersytetu Warszawskiego, Warszawa 2008).

${ }^{57}$ Szersze informacje biograficzne można znaleźć w jego autobiografii (por. Alfred Russel Wallace, My Life: A Record of Events and Opinions, vol. I-II, Chapman \& Hall, London 1905) i licznych anglojęzycznych publikacjach (por. Peter RabY, Alfred Russel Wallace: A Life, Princeton University Press, Princeton 2001; Michael SHermer, In Darwin's Shadow: The Life and Science of Alfred Russel Wallace, Oxford University Press, Oxford - New York 2002; Ross A. Slotten, The Heretic in Darwin's Court: The Life of Alfred Russel Wallace, Columbia University Press, New York 2004; Martin Fichman, An Elusive Victorian: The Evolution of Alfred Russel Wallace, University of Chicago Press, Chicago 2004; William Bryant, Naturalist in the River: The Life and Early Writings of Alfred Russel Wallace, iUniverse, New York 2003; John G. WILSON, The Forgotten Naturalist: In Search of Alfred Russel Wallace, Australia Scholarly Publishing, Melbourne 2000)

${ }^{58}$ Idea uniformitaryzmu została przedstawiona przez Lyella na stronach książki Principles of Geology (por. Charles LyelL, Principles of Geology, vol. 1, John Murray, London 1830; vol. 2, John Murray, London 1832; vol. 3, John Murray, London 1833). Por. też Giovanni Camardi, „Charles Lyell and the Uniformity Principle”, Biology and Philosophy 1999, vol. 14, s. 537-560; Owen ANDERson, „Charles Lyell, Uniformitarianism, and Interpretative Principles”, Zygon 2007, vol. 42 , no. 2 , s. $449-462$.

${ }^{59} \mathrm{~W}$ odróżnieniu od poglądów Lyella wyrażonych w drugim tomie Principles of Geology twierdził jednak, że gatunki są zmienne (por. James T. CosTA, „Engaging with Lyell: Alfred Russel Wallace's Sarawak Law and Ternate Papers as Reactions to Charles Lyell's Principles of Geol-
} 
mieszkujących to zaledwie ostatni etap długiej i nieprzerwanej serii zachodzących zmian". ${ }^{60}$ Zmiany warunków środowiskowych — kontynuował - wywierały presję na organizmy, w budowie których zachodziły stopniowe zmiany, a ich nagromadzenie prowadziło do zmian, które współczesny biolog ewolucyjny określiłby mianem makroewolucyjnych:

[...] życie organiczne na Ziemi przechodziło odpowiednie modyfikacje w zależności od zmian środowiskowych. Choć modyfikacje te miały charakter stopniowy, to ich efekty były całkowite - po pewnym czasie żaden gatunek nie zachował się w swojej uprzedniej formie. Wydaje się, że całkowite przeobrażenie form życia miało miejsce wielokrotnie. ${ }^{61}$

Wallace pisał o naturalnym następstwie gatunków, czyli twierdził, że organizmy żyjące współcześnie wywodzą się z tych, które istniały w przeszłości:

Obecny stan świata organicznego jest w konsekwencji wyraźnym skutkiem naturalnego procesu stopniowego wymierania i pojawiania się gatunków wywodzących się $\mathrm{z}$ tych, które istniały w poprzednich okresach geologicznych. ${ }^{62}$

W powyższym fragmencie mowa jest o „pojawianiu się gatunków”. Wallace użył tutaj wyrażenia „creation of species”, co można by przetłumaczyć jako „stwarzanie gatunków”, a to z kolei wskazywałoby na ich nadnaturalne pochodzenie. Z kontekstu artykułu wynika jednak jasno, że walijski przyrodnik używał terminu „stworzenie” w takim samym znaczeniu jak Darwin — jako pojawienie się gatunków na mocy nieznanego procesu przyrodniczego. ${ }^{63}$ Ponadto

ogy", Theory in Biosciences 2013, vol. 132, no. 4, s. 225-237).

${ }^{60}$ Wallace, „O prawie...”, s. 148.

${ }^{61}$ Wallace, „O prawie...”, s. 148-149.

${ }^{62}$ Wallace, „O prawie...”, s. 149.

${ }^{63}$ Por. Peter Raby, Alfred Russel Wallace: A Life, Princeton University Press, Princeton 2001, s. 103. Por. też Jodкошsкi, Metodologiczne aspekty..., s. 63. John van Wyhe, badacz historii ewolucjonizmu i autor wielu tekstów poświęconych Darwinowi, w obszernej monografii poświęconej Wallace'owi cytował przewodniczącego Towarzystwa Geologicznego, który jeszcze przed publikacją O powstawaniu gatunków oznajmił, że termin „stworzenie” oznacza stwierdzenie pojawienia się danego organizmu bez określenia charakteru tego procesu (por. John VAN WYHE, Dispelling the Darkness: Voyage in the Malay Archipelago and the Discovery of Evolution by Wallace and Darwin, World Scientific Publishing, Singapore 2013, s. 110). 
głównym powodem, dla którego Wallace zdecydował się napisać swój artykuł, była krytyka teorii biegunowości Edwarda Forbesa (1815-1854), a ta miała charakter kreacjonistyczny. ${ }^{64}$

Wallace przewidywał, że poszczególne gatunki połączone są naturalnymi łańcuchami pokrewieństwa, których istnienie można by zobrazować za pomocą linii prostej lub rozgałęzionej:

[...] naturalne łańcuchy pokrewieństwa będą przedstawiały kolejność, w jakiej pojawiały się poszczególne gatunki, z których każdy wywodził się od blisko spokrewnionych gatunków obecnych $\mathrm{w}$ chwili ich pojawienia się. Z pewnością możliwe jest, że dwa czy trzy różne gatunki mogły mieć wspólnego przodka, a każdy z nich mógł dać początek innym blisko spokrewnionym gatunkom. Zatem tak długo, jak każdy gatunek będzie przodkiem tylko jednego zbliżonego sobie gatunku, to ciąg pokrewieństwa będzie prosty i może być przedstawiony przez umieszczenie poszczególnych gatunków w bezpośrednim następstwie w linii prostej. Jeżeli jednak co najmniej dwa gatunki pochodziłyby od różnych wspólnych przodków, wówczas łańcuch pokrewieństwa będzie złożony i może zostać przedstawiony jedynie za pomocą rozwidlonej lub rozgałęzionej linii. ${ }^{65}$

Głównym celem tekstu Wallace'a było przedstawienie prawa, które mogło stanowić wyjaśnienie nie tylko dla ówczesnego rozmieszczenia geograficznego zwierząt i roślin, ale także dla systemu naturalnego pokrewieństwa i występowania organów szczątkowych. Idea sformułowania takiego prawa pojawiła się w jego umyśle po tym, jak zapoznał się z Vestiges. Wallace przyznał, że przez dekadę prowadził obserwacje, które przekonały go o słuszności jego hipotezy. ${ }^{66}$ Zaproponowane prawo brzmiało następująco: „Każdy gatunek pojawił się

${ }^{64}$ Por. Wallace, „O prawie...”, s. 160-164. Forbes wyłożył teorię biegunowości w roku 1844 (por. Edward ForBes, „On the Manifestation of Polarity in the Distribution of Organized Beings in Time", Notices of the Proceedings of the Meetings of the Members of the Royal Institution 1854, vol. 1, s. 428-433; Edward Forbes, ,Anniversary Address of the President”, The Quarterly Journal of the Geological Society of London 1854, vol. 10, s. xxii-lxxxi). Szersze informacje na temat Forbesa i jego teorii można znaleźć w artykule Erica L. Millsa (por. Eric L. Mitls, „A View of Edward Forbes, Naturalist", Archives of Natural History 1984, vol. 11, no. 2, s. 365-393), a także w licznych fragmentach książki Philipa F. Rehbocka (por. Philip F. Reнвоск, The Philosophical Naturalists: Themes in Early Nineteenth-Century British Biology, Wisconsin Publications in the History of Science and Medicine, no. 3, The University of Wisconsin Press, Madison 1983).

${ }^{65}$ Wallace, „O prawie...”, s. 152.

${ }^{66}$ Por. Wallace, „O prawie...”, s. 150. 
współzależnie w czasie i przestrzeni z wcześniej istniejącym i blisko spokrewnionym gatunkiem". ${ }^{67}$ Prawo zaproponowane przez walijskiego przyrodnika znane jest współcześnie jako „Prawo Sarawak”. ${ }^{68}$

Jednym z najbardziej rozpoznawanych symboli teorii ewolucji zaproponowanej przez Darwina było jego „drzewo życia”. ${ }^{69}$ Warto zauważyć, że podobna idea pojawiła się również w tekście Wallace'a:

Tak liczne gatunki oraz tak różnorodne modyfikacje formy i struktury pochodzą prawdopodobnie od ogromnej liczby gatunków, które były przodkami obecnych gatunków, a w konsekwencji odpowiadaja za skomplikowane rozgałęzienia linii pokrewieństwa, tak zawiłe, jak rozgałęzienia sękatego dębu lub układ krwionośny ludzkiego ciała. I jeżeli uwzględnimy to, że dysponujemy jedynie fragmentaryczną wiedzą o tym ogromnym systemie, w którym pień i główne gałęzie reprezentowane są przez nieznane nam wymarłe gatunki, a zbadać należy ogromną liczbę gałęzi, konarów, drobnych gałązek i rozrzuconych liści oraz właściwie ustalić ich pierwotne umiejscowienie w relacji do pozostałych elementów, wówczas cała trudność sporządzenia prawdziwego naturalnego systemu klasyfikacji stanie się dla nas wyraźna. ${ }^{70}$

Walijski przyrodnik podkreślał też znaczenie izolacji geograficznej jako ważnego czynnika stymulującego powstawanie nowych gatunków. Wallace, podobnie jak Darwin, zastanawiał się także nad charakterystycznymi przykładami organizmów, które występowały na wulkanicznych wyspach Galapagos. Również $w$ tym przypadku poszukiwał on naturalnych przyczyn tego zjawiska:

Takie przypadki, jakie zachodzą na wyspach Galapagos, na których występują niewielkie grupy specyficznych roślin i zwierząt najbliżej spokrewnione z tymi z Ameryki Południowej, nie doczekały się dotychczas żadnego, nawet hipotetycznego wyjaśnienia. W skład archipelagu Galapagos wchodzi grupa bardzo wiekowych wysp wulkanicznych i prawdopodobnie nigdy nie znajdowały się one bliżej kontynentu niż ma to miejsce obecnie. Ich początkowe zasiedlanie, podobnie jak innych nowo powstałych wysp, odbywało się z pewnością na skutek działania wiatrów czy prądów oceanicz-

\footnotetext{
${ }^{67}$ Wallace, „O prawie...”, s. 151, 165.

${ }^{68}$ Por. James T. CosTA, Wallace, Darwin, and the Origin of Species, Harvard University Press, Cambridge — London 2014, s. 28.

${ }^{69}$ Por. Niles Eldredge, Darwin: Discovering the Tree of Life, W.W. Norton \& Company, New York - London 2006

${ }^{70}$ Wallace, „O prawie...”, s. 153.
} 
nych. Po okresie dostatecznie dużym, by wymarły gatunki pierwotne, zachowały się tylko te, które uległy przekształceniom. W ten sam sposób możemy wyjaśnić oddzielone wyspy zamieszkałe przez specyficzne gatunki, zakładając, że albo wszystkie wyspy zostały zajęte równocześnie przez te same gatunki, które dały początek różnym modyfikacjom, albo że wyspy były stopniowo zasiedlane jedna po drugiej, ale na każdej nowe gatunki powstały $\mathrm{z}$ wcześniej istniejących organizmów. ${ }^{71}$

Wallace zastanawiał się również nad występowaniem organów szczątkowych. Twierdził, że ich obecność w zapisie kopalnym jest argumentem przeciwko koncepcjom niezależnego (specjalnego) stworzenia, które były powszechne do czasów opublikowania $\mathbf{O}$ powstawaniu gatunków. ${ }^{72}$ Natomiast w opinii Wallace'a organy szczątkowe były świadectwem na rzecz prawa wyłożonego w jego artykule, łączącego poszczególne gatunki wspólnym pochodzeniem i przemawiającego na rzecz tezy, że w każdej epoce geologicznej istniała ogromna liczba gatunków:

Zatem powierzchnia Ziemi w każdej epoce była bez wątpienia teatrem życia, podobnym do tego, który istnieje obecnie. Kiedy wymarły kolejne pokolenia każdego gatun$\mathrm{ku}$, to ich wylinka i części ciała mogące ulec zachowaniu pozostawiły ślad każdej części istniejących wówczas mórz i oceanów, które — jak mamy powody sądzić — miały większy zasięg niż obecne. ${ }^{73}$

W roku 1855 Wallace nie znał jeszcze darwinowskiej „tajemnicy tajemnic” — teorii doboru naturalnego. ${ }^{74}$ Jednakże był już wówczas przekonany, że „Odkrycie, w jaki sposób w obecnym okresie geologicznym wypełniane są luki po wygasłych gatunkach, przysparza wielu trudności, ale zarazem jest to najbardziej interesujące zagadnienie w historii naturalnej Ziemi". ${ }^{75}$ Walijski przyrodnik opierał się jedynie na ogólnym stwierdzeniu, że „[...] czynnikiem decydują-

\footnotetext{
${ }^{71}$ Wallace, „O prawie...”, s. 155.

${ }^{72}$ Por. David Briggs, Plant Microevolution and Conservation in Human-Influenced Ecosystems, Cambridge University Press, Cambridge - London 2009, s. 18. Por. też Keith Thomson, Before Darwin: Reconciling God and Nature, Yale University Press, New Haven 2005.

${ }^{73}$ Wallace, „O prawie...”, s. 163.

${ }^{74}$ Por. Marc Ereshefsky, „Mystery of Mysteries: Darwin and the Species Problem”, Cladistics 2011, vol. 27, no. 1, s. 67-79.

${ }^{75}$ Wallace, „O prawie...”, s. 158.
} 
cym w procesie powstawania i wymierania gatunków są warunki środowiskowe". ${ }^{76}$ Tekst Wallace'a należy uznać za swojego rodzaju preludium względem tego, co napisał podczas pobytu na wyspie Ternate na początku 1858 roku.

\section{Zakończenie}

Zdaniem niektórych uczonych teoria Darwina „wisiała w powietrzu” na długo przed jej opublikowaniem. ${ }^{77}$ Przedmiotem niniejszego artykułu była próba wskazania na najważniejsze poglądy Matthew, Blytha i Wallace'a, które miały związek z teorią Darwina i które zostały ujęte w tekstach opublikowanych przed pierwszym wydaniem $\mathbf{O}$ powstawaniu gatunków. I chociaż należy przyznać, że każdy ze wskazanych autorów przedstawił fragmenty tego, co dzisiaj nazywamy darwinizmem (włączając $\mathrm{w}$ to teorię doboru naturalnego czy analogię pomiędzy selekcją w warunkach hodowlanych i w stanie natury), to w żaden sposób nie umniejsza to zasług Darwina.

Grzegorz Malec

\section{Evolution Before Darwin: Matthew, Blyth, Wallace}

\section{Summary}

The main aim of this article is the analysis of the papers which had been published before the first publication of Darwin's On the Origin of Species by Means of Natural Selection, or the Preservation of Favoured Races in the Struggle for Life. The authors of these publications are Patrick Matthew (1831), Edward Blyth (1835), and Alfred Russel Wallace (1855). So far, these texts were scarcely an object of interest of Polish scholars but are important in the history of the theory of evolution.

Keywords: Alfred Russel Wallace, Edward Blyth, Patrick Matthew, theory of natural selection, theory of evolution.

Slowa kluczowe: Alfred Russel Wallace, Edward Blyth, Patrick Matthew, teoria doboru naturalnego, teoria ewolucji.

\footnotetext{
${ }^{76}$ Wallace, „O prawie...”, s. 161.

${ }^{77}$ Por. Conway ZirkLe, „Natural Selection Before «Origin of Species»”, Proceedings of the American Philosophical Society 1941, vol. 84, no. 1, s. 104 [71-123].
} 